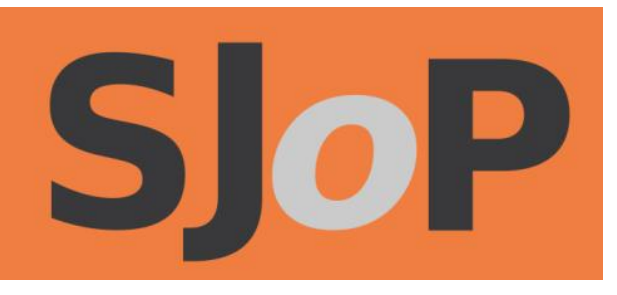

\title{
Salad lunch and gift instructions
}

\section{THE ART OF CARE-FULL PRACTICE SYMPOSIUM}

The Scottish Journal of Performance

Volume 5, Issue 1; April 2018

ISSN: 2054-1953 (Print) / ISSN: 2054-1961 (Online)

Publication details: http://www.scottishjournalofperformance.org

To cite this article: The Art of Care-full Practice Symposium, 2018. Salad lunch and gift instructions. Scottish Journal of Performance, 5(1): pp. 101-102.

To link to this article: http://doi.org/10.14439/sjop.2018.0501.11

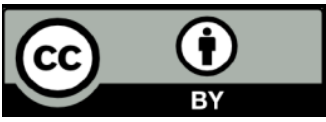

This work is licensed under a Creative Commons Attribution 4.0 International License. See

http://creativecommons.org/licenses/by/4.0/ for details. 


\title{
Salad lunch and gift instructions
}

\author{
THE ART OF CARE-FULL PRACTICE SYMPOSIUM
}

DOI: 10.14439/sjop.2018.0501.11

Publication date: 6 April 2018

\section{The Art of Care-full Practice}

\section{Salad lunch and gift instructions}

We have provided you with bowls, lettuce, salad dressing, toppings, bread, chopping materials, cutlery, plates, soft drinks and cups.

With the materials you have brought for lunch, negotiate with your group about what to include in the salad and how.

You may want to continue the discussion on care. Nutritious food is a great invitation to converse.

What is the relation between food and care?

Enjoy the lunch you have created as a group.

Sometime during the lunch, discuss how you want to pass on the gift or token of care you have brought.

What is the relation between care, giving and receiving?

The paper acting as table cloth is a document. Feel free to write anything you want on it.

There is no need to conclude on anything, just to open up conversations. 


\section{About the authors}

This material was prepared by Laura Bissell, Laura González, Dee Heddon and Simon Murray, organisers of The Art of Care-full Practice symposium, which took place on 5 March 2017 at the University of Glasgow. This event was a collaboration between The Royal Conservatoire of Scotland, The Glasgow School of Art and the University of Glasgow, and was part of the inaugural Take $\mathrm{Me}$ Somewhere festival of contemporary performance that took place in various locations in Glasgow. 